\title{
Genetic determination of the prognosis in survivors of acute coronary syndromes. Study design and rationale for a multicenter study*
}

\author{
Jan Pitha, Jaroslav A. Hubáček, Rudolf Poledne, Vladimír Staněk*, Michael Aschermann**, \\ Marie Gebauerová*, Petr Hájek***, Petr Niederle****, Martin Pěnička*****, Josef Veselka*** \\ Laboratory for Atherosclerosis Research, *Clinic of Cardiology, Institute for Clinical and Experimental Medicine, \\ ${ }^{* *}$ General Teaching Hospital, Second Department of Internal Medicine and Charles University Medical Faculty 1, \\ ***CardioVascular Center, Department of Cardiology, Motol University Hospital, \\ ****Department of Cardiology, Na Homolce Hospital, *****Cardiocenter, Department of Cardiology, \\ Králouské Vinohrady University Hospital and Third Medical Faculty, Prague, Czech Republic
}

Pitha J, Hubáček JA, Poledne R, Staněk V*, Aschermann $\mathrm{M}^{* *}$, Gebauerová $\mathrm{M}^{*}$, Hájek $\mathrm{P}^{* * *}$, Niederle $\mathrm{P}^{* * * *}$, Pěnička $\mathrm{M}^{* * * * *}$ Veselka $J^{* * *}$ (Laboratory for Atherosclerosis Research, *Clinic of Cardiology, Institute for Clinical and Experimental Medicine, **General Teaching Hospital, Second Department of Internal Medicine and Charles University Medical Faculty 1, ***CardioVascular Center, Department of Cardiology, Motol University Hospital, ****Department of Cardiology, Na Homolce Hospital, *****Cardiocenter, Department of Cardiology, Královské Vinohrady University Hospital and Third Medical Faculty, Prague, Czech Republic). Genetic determination of the prognosis in survivors of acute coronary syndromes. Study design and rationale for a multicenter study. Cor Vasa 2007;49(4):134-137.

Powerful predictors have already been established for clinical complications ensuing from acute coronary events. Despite this, substantial differences exist between patients at apparently similar risk. Amongst the most frequently discussed newer predictors of clinical events are genes and their interactions. Identification of disadvantageous variants of candidate genes could help to detect the patients suitable for more consistent follow-up and the best possible treatment. The two main aims of this study are, first, identification of the particular alleles and genotypes responsible for acute coronary events in a large population of Czech patients in a cross-sectional study and, second, determination of the effect of these alleles on clinical outcomes in a prospective study. A total of 2,500 patients with acute coronary syndromes from 5 coronary care units based in Prague are to be recruited. A control group is to comprise a representative $1 \%$ population sample of 2,600 individuals. The polymorphisms of the following most frequently discussed single genes are to be studied: the connexin 37 gene, stromelysin-1 gene, plasminogen activator-inhibitor type 1 gene, and the lymphotoxin-alpha gene.

Key words: Acute coronary syndrome - Genetic polymorphism - Population-based study

Pitha J, Hubáček JA, Poledne R, Staněk V*, Aschermann $\mathrm{M}^{* *}$, Gebauerová $\mathrm{M}^{*}$, Hájek P***, Niederle $\mathrm{P}^{* * * *}$, Pěnička M*****, Veselka $J^{* * *}$ (Laboratoř pro výzkum aterosklerózy, *Klinika kardiologie, Institut klinické a experimentální medicíny, **II. interní klinika, Všeobecná fakultní nemocnice a 1. lékařská fakulta Univerzity Karlovy, ***Kardiovaskulární centrum, Klinika kardiologie, Fakultní nemocnice Motol, ****Oddělení kardiologie, Nemocnice Na Homolce, *****Kardiocentrum, Klinika kardiologie, Fakultní nemocnice Královské Vinohrady a 3. lékařská fakulta Univerzity Karlovy, Praha, Česká republika). Genetická determinace prognózy pacientů po akutním koronárním syndromu. Uspořádání studie a zdůvodnění multicentrické studie. Cor Vasa 2007;49(4):134-137.

Byla již popsána řada významných faktorů určujících výskyt klinických komplikací u pacientů po akutním koronárním syndromu. I přesto jsou patrné výrazné interindividuální rozdíly v následném osudu těchto pacientů s podobným rizikovým profilem. V těchto odlišnostech hrají jednoznačně významnou úlohu genetické faktory. Pomocí stanovení nevýhodných genů a jejich kombinací bychom mohli vytipovat pacienty vhodné pro podrobnější diagnostické sledování a případně i optimální léčbu. Hlavním cílem právě zahájené multicentrické studie je detekce nevýhodných genových alel a genotypů, jednak z hlediska vzniku akutních koronárních př́íhod v průřezové studii, jednak $\mathrm{z}$ hlediska vzniku komplikací následujících po vzniku těchto př́hod ve studii longitudinální. V první fázi studie bude vyšetřeno 2500 mužů a žen přijatých s akutním koronárním syndromem na pěti pražských koronárních jednotkách. Kontrolní skupinou bude již vyšetřený reprezentativní $1 \%$ populační vzorek 2600 mužů a žen z České republiky. Budou stanoveny varianty genů, které patří v současnosti k nejvíce diskutovaným: gen pro connexin 37 , gen stromelysinu 1 , gen inhibitoru aktivátoru plazminogenu typ 1 , a gen lymfotoxinu alfa. Klíčová slova: Akutní koronární syndrom - Genetické polymorfismy - Populační studie

Address: MUDr. Jan Pitha, CSc., Laboratory for Atherosclerosis Research, Institute for Clinical and Experimental Medicine, Vídeňská 1958/9, 14021 Prague 4, Czech Republic, e-mail jan.pitha@ikem.cz

*This work was supported by grant NR/9093-4/2006 of the Internal Grant Agency

of the Ministry of Health of the Czech Republic. 


\section{BACKGROUND}

Several powerful predictors of short and long-term event-free survival after myocardial infarction have already been identified. These are available from the patients history, physical examination, initial electrocardiogram and, more recently, from echocardiography, angiography, and blood testing. Despite the strong prognostic value of these factors, striking differences still exist in the prevalence of clinical events between patients at similar risk.

Advances in the molecular approach to cardiovascular disease will allow better understanding of these inter-individual differences and will offer more effective detection of those at risk as well as more effective therapeutic strategies to prevent subsequent clinical complications. Amongst the most frequently discussed newer predictors of clinical events are, first and most importantly, genes and their interactions (gene-gene interactions, gene-environment interactions). Therefore, identification of these candidate genes could improve preventive strategies in patients with coronary heart disease.

As atherosclerosis and coronary heart disease are complex diseases, many genes (with latest estimates varying from 500 to 800 genes) involved in pathophysiological process participate in the development of these conditions, from the onset of atherosclerosis to its clinical manifestation.

The human genome seems to contain about 25,000 to 30,000 genes. The number of proteins in the human body (estimated to be 70,000 to 100,000 ) is much higher than that of genes, as some genes encode more than one protein due to alternative splicing and posttranslational modifications.

Two extreme models of development of a common disease have been suggested, and both are applicable to cardiovascular disease. One model is based on a large number of alleles with minor effects, and forming various genes interacting with each other and with the environment to cause cardiovascular disease (polygenic model). The second model is based on rare alleles with major effects, and forming a large number of genes which cause cardiovascular disease (monogenic model). In the case of atherosclerosis, the complex model involves a combination of these two possibilities.

Several large epidemiological studies have been published. On one hand, these studies have shown the strong genetic determination of coronary events and their complications. On the other hand, the results of these studies have not led to consistent conclusions.

From a large study of almost 21,000 twins, it has been calculated that cardiovascular disease has a significant heritability component of $\sim 60 \%$ in males and $\sim 40 \%$ in females. ${ }^{(1)}$ In addition, the risk of premature cardiac death was eight times higher in males and fifteen times higher in females whose siblings died because of a heart attack before ages 55 and 65 years, respectively. ${ }^{(2)}$

Because of the high number of candidate genes and putative high-risk gene polymorphisms, the identification of genetic variants that play a role in the pathogenesis of coronary artery disease is difficult. One possibility for candidate gene identification is to determine their disadvantageous variants/ polymorphisms. The effect of these variants is being assessed worldwide in ongoing studies with different designs. Despite thousands of studies, controversial results regarding many candidate genes for cardiovascular disease have been published. There are several reasons for these discrepancies. Perhaps the most important one is the fact that the majority of genetic studies included inadequate numbers of patients and controls, averaging between 100 and 300 individuals. The power of such studies is low and the risk of obtaining false positive or false negative results is high.

Nevertheless, in recent years, studies have been published whose authors examined large numbers of patients with acute coronary syndrome. These include between 500 and 1,000 patients enrolled in the studies of the HIFMECH group (including 550 patients after myocardial infarction), (3) 650 consecutive Taiwanese patients diagnosed with acute coronary syndrome $\mathrm{e}^{(4)}$ and a cohort of 752 British patients suffering from myocardial infarction. ${ }^{(5)}$ A prospective cohort study of 735 patients with acute coronary syndromes, and treated by beta-blockers, revealed the possible role of the beta 2-adrenergic receptor polymorphism in the chances of survival. ${ }^{(6)}$ Results from even larger studies were published assessing data in $\sim 1,800$ patients with myocardial infarction ${ }^{(7)}$ and in $\sim 1,350$ myocardial infarction cases in the LURIC study. ${ }^{(8)}$ The largest study published to date is the ISIS study (International Study of Infarction Survival) involving almost 7,000 non-fatal myocardial infarction cases and 2,700 unrelated controls. ${ }^{(9)}$

Another two very complex genetic studies were conducted in Japan, a country with a low incidence of coronary heart disease. ${ }^{(10,11)}$ These studies revealed polymorphisms of four genes most important for

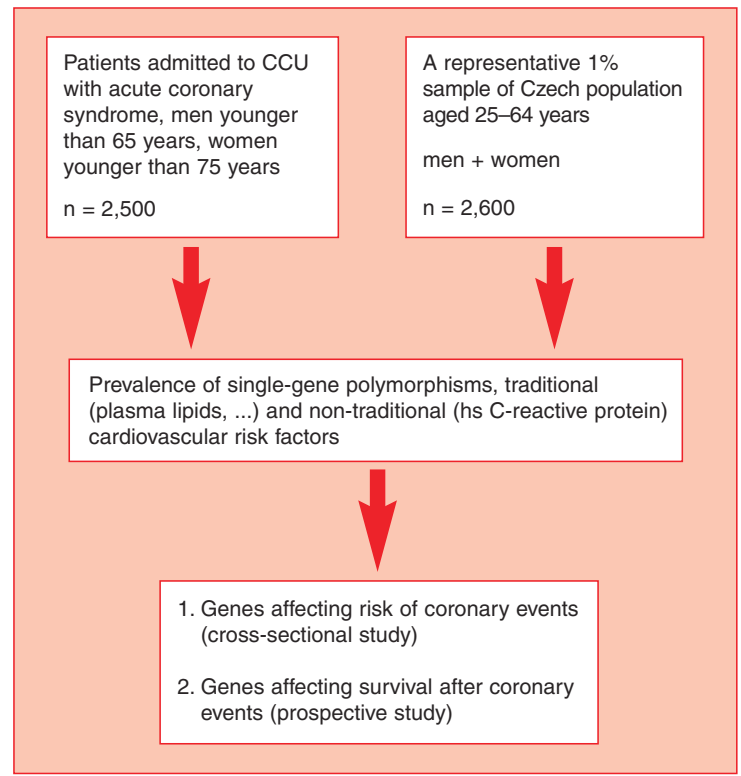

Figure 1 Design of the genetic study in patients with acute coronary syndromes

CCU - coronary care unit 
Table I

Candidate genes for cardiovascular disease

\begin{tabular}{lll}
\hline \hline Gene & Potential mechanism(s) & References \\
\hline Connexin-37 & $\begin{array}{l}\text { Impaired inter-cell communication causing increased adhesion } \\
\text { of monocytes to the endothelium. }\end{array}$ & $10,17,18,19$ \\
\hline Stromelysin-1 & Matrix metalloproteinase causing instability of the atherosclerotic plaque. & 10,20 \\
\hline $\begin{array}{l}\text { Plasminogen } \\
\text { activator-inhibitor type 1 }\end{array}$ & $\begin{array}{l}\text { Increased plasma thrombogenicity; occlusion of the affected } \\
\text { artery by thrombus. }\end{array}$ & 10,21 \\
\hline Lymphotoxin-alpha & Increased inflammation of the vessel wall, increased plaque instability. & $9,10,11,19$ \\
\hline \hline
\end{tabular}

survival after myocardial infarction. This analysis (of 112 genes) identified four genes encoding the following proteins as risk factors: connexin 37 (only in males), stromelysine- 1 and the plasminogen activator inhibitor-1 (only in females), lymphotoxin-1 (in both genders). However, generalization of these results, mainly in European populations, is questionable. It is a well-known fact that the frequencies of individual alleles can differ substantially in European and Asian populations and, in some cases, the alleles are even ethnic-specific; in addition, the incidence of coronary heart disease is substantially higher in Europe compared with Japan.

Another possible cause of the inconsistent findings in this area is that the analyzed variant by itself is not functional. Results from epidemiological studies may thus not be reproducible if the rate of linkage disequilibrium (allelic association) differs between various populations. This applies mainly to different ethnicities. However, even in Europe, within the same ethnicity, the allelic frequency may differ substantially between different populations. For example, the apolipoprotein E4 allele (associated with elevated plasma cholesterol levels) occurs in Finland with a frequency of $\sim 23 \%$ while the frequency is $\sim 12 \%$ in the Czech population. ${ }^{(12)}$

Additionally, various environmental factors (smoking, dietary habits, etc.) in different geographical areas interact with the genetic variants. The implication is that an unconfirmed association is not necessarily a genuine "false positive", one and may simply reflect different environmental conditions in the different study groups. This fact is also underestimated and rarely discussed.

\section{RATIONALE FOR AND DESIGN OF THE STUDY}

Thanks to the efforts of our cardiologists, the Czech Republic currently belongs to the countries with the best standard of care of patients with acute forms of coronary heart disease. ${ }^{(13,14)}$ However, these patients are still at high risk of recurrent coronary events, coronary death, and development of congestive heart failure and stroke in the ensuing years. Thus, identification of disadvantageous variants of candidate genes could help to detect patients suitable for more intensive follow-up and the best possible therapeutic efficacy.

\section{Aims of the study}

1. To identify the alleles and genotypes responsible for acute coronary events in a large population of Czech patients

(a cross-sectional study).

2. To determine whether some alleles are the risk factors for recurrent coronary events and their consequences in the Czech population (a prospective study).

\section{Study population}

The project will recruit a total of 2,500 patients with myocardial infarction in 5 coronary care units based in Prague (Department of Cardiology, Institute for Clinical and Experimental Medicine; Second Department of Internal Medicine, Charles University Medical Faculty I, General Teaching Hospital; Department of Cardiology, Na Homolce Hospital; Cardiocenter, Department of Cardiology, Královské Vinohrady University Hospital and Medical Faculty III, CardioVascular Center, Department of Cardiology, Motol University Hospital). All males younger than 65 years and females younger than 75 years hospitalized in selected coronary units for acute coronary syndrome with increased troponin levels, i.e., acute myocardial infarction and minimal myocardial lesion, and patients with subacute myocardial infarction will be enrolled into this project. The only exclusion criteria are age and refusal to participate in the study.

The standard questionnaire focused on the presence of conventional cardiovascular risk factors including family and personal histories will be completed for each individual after informed consent. This questionnaire contains questions similar to those of the Acute Coronary Syndromes Registry and the MONICA (MONItoring of CArdiovascular disease) study. Venous blood will be sampled for the determination of plasma lipid levels, C-reactive protein measured by a highly sensitive method and other biochemical markers, and for leukocyte DNA extraction and immortalization of B-lymphocytes. DNA analysis will be performed on a routine basis using high-throughput PCR and RFLP techniques. ${ }^{(15,16)}$

\section{Control group}

A representative 1\% sample of the Czech population aged between 25 and 64 years was selected as part of the WHO-sponsored MONICA study in the districts of Benešov, Praha východ (Prague East), Cheb, Chrudim, Jindřichův Hradec, Pardubice, Kroměříž, Litoměřice, and Plzeň město (Pilsen City) $(2,600$ individuals) in the years 2000-2001. Comparing our large group of Czech myocardial infarction survivors to this representative control group seems to be the main 
advantage of this project because selection of an inappropriate control group may be the main cause of inconsistencies seen in numerous epidemiologicalgenetic studies.

\section{Genes under study}

Of the group of recently discussed candidate genes for cardiovascular disease, the single-gene polymorphisms in the four recently discussed genes are to be studied (Table I): the gene for connexin-37 (gap junction protein, responsible for inter-cell communication), the gene for stromelysin-1 (a metalloproteinase responsible for atherosclerotic plaque destabilization), the gene for plasminogen activator-inhibitor type 1 (a protein responsible for the prothrombogenic status of plasma), and the gene for lymphotoxin-alpha (a toxin from lymphocytes responsible for inflammatory processes in the arterial wall leading to initiation, progression and destabilization of atherosclerotic plaques). In addition, plasma and DNA from all patients will be stored for further biochemical and genetic analysis.

\section{Data analysis and outcomes}

In a cross-sectional analysis, the differences in selected genotypes between patients with acute coronary syndromes and the general population will be assessed by an unpaired $t$-test (age-adjusted statistical model).

The information about date and cause of death will be obtained for all deceased patients and for all deceased participants in the general population from the Health Information and Statistics Institute of the Czech Republic at one and two years of follow-up. Information about hospitalization for any cardiovascular event is to be recorded for each participant during the follow-up. Event-free survival will be assessed by Kaplan-Mayer analysis and statistical differences according to various genotypes will be calculated using the log-rank test.

\section{CONCLUSION}

Given the large number of non-selected patients and a well-defined control group (a representative sample of the Czech population), we expect to obtain reliable data on the predictive role of the genotype, mainly as regards the survival rates of patients with acute coronary syndrome.

\section{REFERENCES}

1. Zdravkovic S, Wienke A, Pedersen NL, Marenberg ME, Yashin AI, De Faire U. Heritability of death from coronary heart disease: a 36-year follow-up of 20966 Swedish twins. J Intern Med 2002;252:247-54.

2. Marienberg ME, Risch N, Bergman LF, Floderus B, de Faire U. Genetic susceptibility to death from coronary heart disease in a study of twins. New Engl J Med 1994; 330: 1041-6.

3. Morange PE, Henry M, Frere C, Juhan-Vague I; HIFMECH study group. Thr325IIe polymorphism of the TAFI gene does not influence the risk of myocardial infarction. Blood 2002;99:1878-9.

4. Liu PY, Li YH, Chan SH, et al. Genotype-phenotype association of matrix metalloproteinase-3 polymorphism and its synergistic effect with smoking on the occurrence of acute coronary syndrome. Am J Cardiol 2006;98:1012-7.

5. Mangino M, Braund P, Singh R, et al. LGALS2 functional variant rs7291467 is not associated with susceptibility to myocardial infarction in Caucasians. Atherosclerosis 2006 [Epub ahead of print].

6. Lanfear DE, Jones PG, Marsh S, Cresci S, McLeod HL, Spertus JA. Beta2-adrenergic receptor genotype and survival among patients receiving beta-blocker therapy after an acute coronary syndrome. JAMA 2005;294: 1526-33.

7. Shiffman D, Rowland CM, Louie JZ, et al. Gene variants of VAMP8 and HNRPUL1 are associated with early-onset myocardial infarction. Arterioscler Thromb Vasc Biol 2006;26:1613-8.

8. Winkelmann BR, Marz W, Boehm BO, et al. Rationale and design of the LURIC study-a resource for functional genomics, pharmacogenomics and long-term prognosis of cardiovascular disease. Pharmacogen 2001;2:S1-S73.

9. Clarke R, Xu P, Bennett D, et al. International Study of Infarct Survival (ISIS) Collaborators Lymphotoxin-alpha gene and risk of myocardial infarction in 6,928 cases and 2,712 controls in the ISIS case-control study. PLoS Genet 2006;2:e107.

10. Yamada Y, Izawa H, Ichihara S, et al. Prediction of the risk of myocardial infarction from polymorphisms in candidate genes. New Engl J Med 2002;347:1916-23.

11. Ozaki K, Ohnishi Y, Iida A, et al. Functional SNPs in the lymphotoxin-alpha gene that are associated with susceptibility to myocardial infarction. Nat Genet 2002; 32:650-4.

12. Hubáček JA, Poledne R. Apolipoprotein E and its role in lipid metabolism, cardiovascular disease and Alzheimer disease. Prakt Lék 1998;78:162-5.

13. Widimsky P, Budesinsky T, Vorac D, et al. 'PRAGUE' Study Group Investigators. Long distance transport for primary angioplasty vs immediate thrombolysis in acute myocardial infarction. Final results of the randomized national multicenter trial-PRAGUE-2. Eur Heart J 2003; 24:94-104.

14. Stanek V, Gebauerová M, Horák J, et al. Change in the fate of middle-aged men with acute myocardial infarction. Cor Vasa 2004;46:319-25.

15. Day N, Humphries SE. Electrophoresis for genotyping: microtiter array diagonal gel electrophoresis on horizonta polyacrylamide gels, hydrolink, or agarose. Anal Biochem 1994;222:389-95.

16. Hubáček JA. PCR - polymerase chain reaction. Principles and applications in research and medical practice. Čas Lék čes 1996;135:611-3.

17. Wong CW, Christen T, Roth I, et al. Connexin 37 protects against atherosclerosis by regulating monocyte adhesion. Nat Med 2006;12:950-4.

18. Wong CW, Christen T, Pfenniger A, James RW, Kwak BR. Do allelic variants of the connexin37 1019 gene polymorphism differentially predict for coronary artery disease and myocardial infarction? Atherosclerosis 2006; [Epub ahead of print].

19. Mizuno H, Sato H, Sakata Y, et al. Osaka Acute Coronary Insufficiency Study (OACIS) Group. Impact of atherosclerosis-related gene polymorphisms on mortality and recurrent events after myocardial infarction. Atherosclerosis 2006; 185:400-5.

20. Liu PY, Li YH, Chan SH, et al. Genotype-phenotype association of matrix metallo-proteinase-3 polymorphism and its synergistic effect with smoking on the occurrence of acute coronary syndrome. Am J Cardiol 2006;98:1012-7

21. Ding J, Nicklas BJ, Fallin MD, et al. Plasminogen activator inhibitor type 1 gene polymorphisms and haplotypes are associated with plasma plasminogen activator inhibitor type 1 levels but not with myocardial infarction or stroke. Am Heart J 2006;152:1109-15.

Received 6 February 2007

Accepted 2 March 2007 